\title{
GROSPYDITE XENOLITHS FROM GRIB PIPE KIMBERLITES (ARKHANGELSK PROVINCE, RUSSIA)
}

\author{
Sablukova LI ${ }^{1}$, Sablukov SM ${ }^{1}$, Verichev EM ${ }^{2}$ and Antonov AV ${ }^{3}$ \\ 1 Rusgeo Ltd, Moscow, Russia, \\ 2 Arkhangelskgeoldobycha Co. Ltd., Arkhangelsk, Russia, \\ 3 VSEGEI, Centre for Isotope Research, St.-Petersburg, Russia
}

\section{INTRODUCTION}

The "grospydite" xenoliths, i.e. GROSsular(clino)PYroxene-DIstene(kyanite) rocks (Bobrievich et al., 1959) are rarely observed in kimberlites. They were identified in pipes of Yakutia (Udachnaya, Sytykanskaya, Zarnitsa, and Zagadochnaya) and Africa (Roberts Victor and Bellsbank). Finding of grospydite xenoliths in kimberlites of the Russian Platform was the first. Grospydites are characterized not only by their original composition but also by belonging to the potentially diamond-bearing mantle rocks. Therefore, the study of grospydites xenoliths in new kimberlite areas is of obvious interest. In this paper, we apply the results of our study of grospydite xenoliths from the Grib kimberlite pipe, in the Zimni Bereg region (Arkhangelsk Province of Russia).

\section{MAGMATIC ROCKS OF THE ZIMNI BEREG REGION}

The Zimni Bereg diamond-bearing region of Russia is globally unique; it has two full Late Devonian kimberlite series (Al-series and Fe-Ti series) that are distinct in structure and composition, and differentiated from highly diamondiferous kimberlites to barren melilitites and picrites occurring together with basaltic volcanic pipes of the same age (Fig. 1).

The Al-series rocks (being somewhat similar to Group 2 kimberlites) form a sequence (row) from diamondiferous kimberlites of the Zolotitsky pipe cluster (the Lomonosov deposit) to kimmelilitites and olivine melilitites of Verkhotina, Chidviya, Izhma and Suksoma,. The Fe-Tiseries rocks (analogues to Group 1 kimberlites) form a row from diamondiferous kimberlites of the Grib pipe (the Grib deposit) and poorly diamondiferous kimberlites of Pachuga to kimpicrites and melilite picrites of Shocha, Kepina, Soyana, Pachuga and Megra.

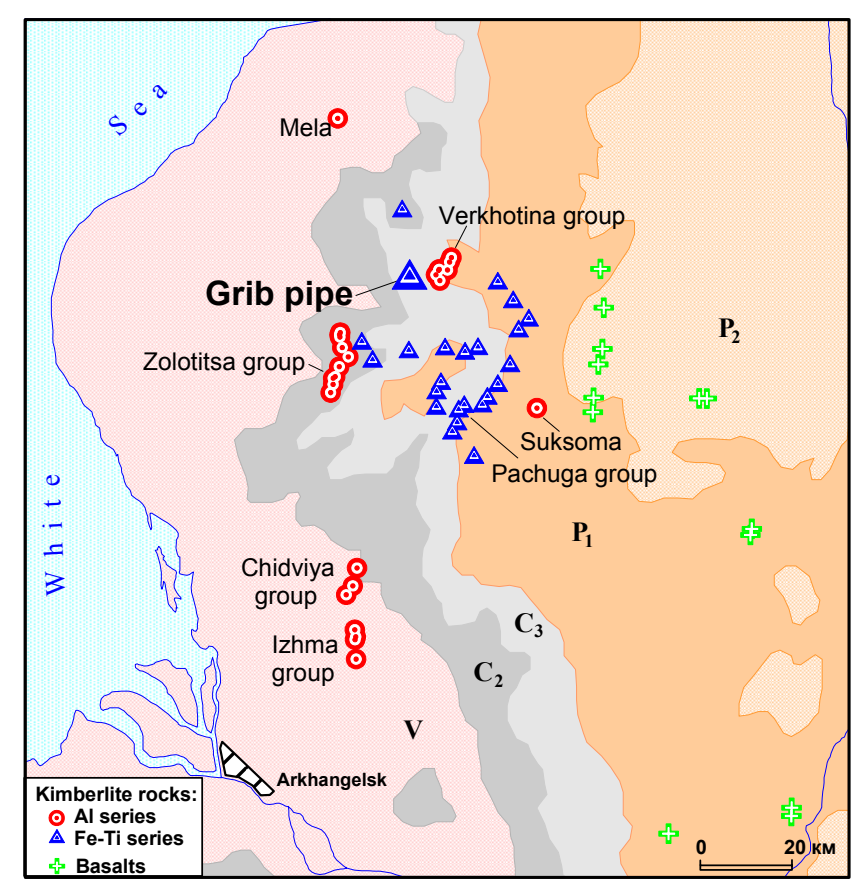

Fig. 1. Distribution of volcanic rocks on the Zimni Bereg region.

\section{GROSPYDITE XENOLITHS}

In kimberlites of Grib pipes one can find a large number of mantle xenoliths (Sablukova et al., 2003) including xenoliths of various eclogites. Eclogites of A and B groups (Coleman et al., 1965) dominate; eclogites of group $\mathrm{C}$ are rarer, as well as macrocrysts of eclogitic paragenesis. In kimberlites of this pipe we have found 2 xenoliths of grospydites and macrocrysts of high-calcuim (highgrossular) garnets of eclogite paragenesis and omphacitejadeites. 


\section{$10^{\text {th }}$ International Kimberlite Conference, Bangalore - 2012}

\section{Appearance and mineralogy}

Xenoliths are oval in form, $5.5 * 3.5 \mathrm{~cm}$ and $3.6 * 2.9 \mathrm{~cm}$ in size, and are characterized by similar modal compositions: $\operatorname{gar}(40)+\mathrm{cpx}(40)+\mathrm{ky}(20)$ for sample $77 / 691$ and $\operatorname{gar}(20)+\operatorname{cpx}(50)+\mathrm{ky}(30)$ for sample $96 / 296$. The rock texture is medium-crystalline (grains are 3-4 $\mathrm{mm}$ in size), while the structure is massive (Fig. 2). Garnet and distene form isometric euhedral and subeuhedral grains in the clinopyroxene matrix.

Yellow-orange garnet (Table-1) is characterized by composition typical of grospydites (67.0 and $56.8 \%$ of grossular minal, respectively) at the high $\mathrm{Fe}$ content ( $\mathrm{f}=$ 51.8 and $48.7 \%$ ). Clinopyroxene is replaced completely by the serpentine group minerals. White kyanite with a paly blue shade is characterized by a standard composition and virtually does not contain any impurities.

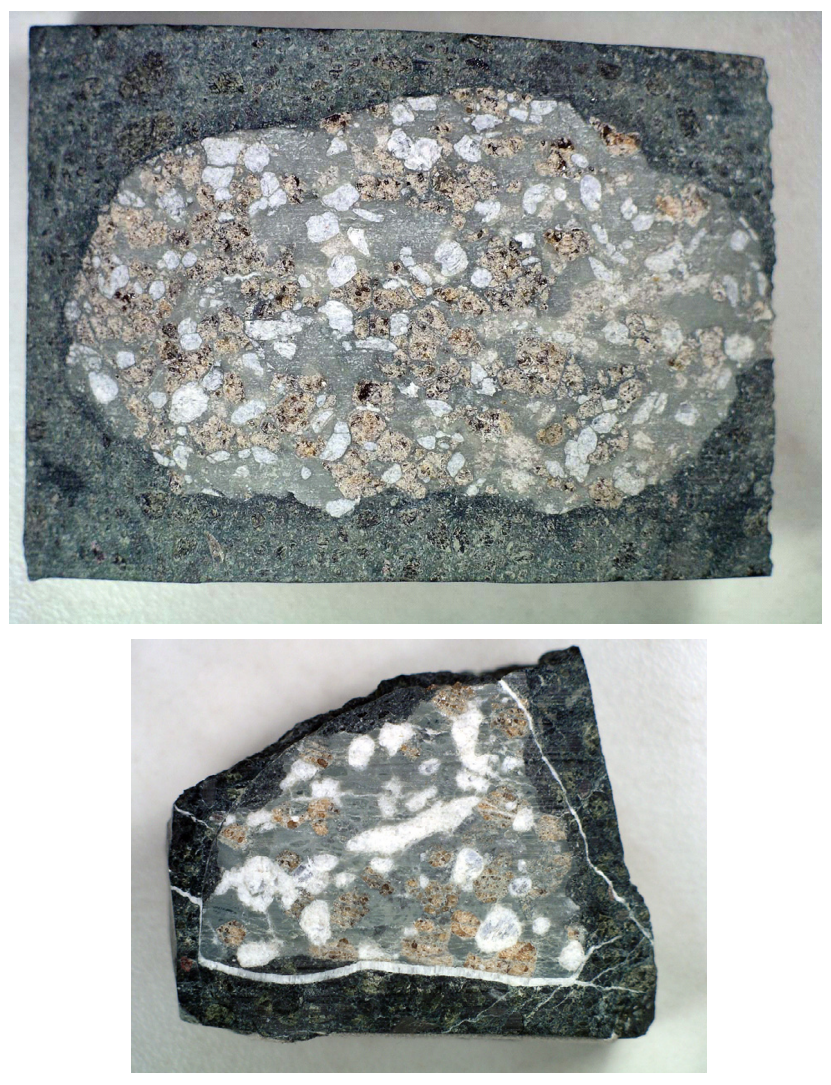

Fig. 2. Grospydite xenoliths in the Grib pipe: top - sample 77/691; bottom - sample 96/296.

Microelement and isotopic compositions of oxygen in garnet from grospydites were compared to those of garnets from various eclogites of the Grib pipe.
Table-1. Chemical (wt. \%) and oxygen isotope composition of grospydite minerals.

\begin{tabular}{|c|r|r|r|r|}
\hline \multirow{2}{*}{ Sample } & \multicolumn{2}{|c|}{$77 / 691$} & \multicolumn{2}{c|}{$96 / 296$} \\
\hline Minerale & \multicolumn{1}{|c|}{ Grt } & \multicolumn{1}{c|}{ Ky } & \multicolumn{1}{c|}{ Grt } & \multicolumn{1}{c|}{ Ky } \\
\hline $\mathrm{SiO}_{2}$ & 40.41 & 36.71 & 40.36 & 36.70 \\
\hline $\mathrm{TiO}_{2}$ & 0.33 & 0.05 & 0.22 & 0.03 \\
\hline $\mathrm{Al}_{2} \mathrm{O}_{3}$ & 22.03 & 62.59 & 22.29 & 62.55 \\
\hline $\mathrm{Cr}_{2} \mathrm{O}_{3}$ & 0.10 & 0.02 & 0.05 & 0.01 \\
\hline $\mathrm{FeO}$ & 7.86 & 0.06 & 9.95 & 0.10 \\
\hline $\mathrm{MnO}$ & 0.08 & 0.03 & 0.17 & 0.00 \\
\hline $\mathrm{MgO}$ & 4.10 & 0.01 & 5.59 & 0.07 \\
\hline $\mathrm{CaO}$ & 25.55 & 0.00 & 22.04 & 0.01 \\
\hline $\mathrm{Na}_{2} \mathrm{O}$ & 0.06 & 0.00 & 0.14 & 0.04 \\
\hline $\mathrm{K}_{2} \mathrm{O}$ & - & 0.01 & & 0.02 \\
\hline $\mathrm{Total}$ & 100.52 & 99.48 & 100.81 & 99.53 \\
\hline $\mathrm{Grossular}_{0} \%$ & 67.0 & - & 57.8 & - \\
\hline$\delta^{18} \mathrm{O}, \%$ & 4.99 & - & 5.60 & - \\
\hline & & & & \\
\hline
\end{tabular}

\section{Trace elements}

Trace-element analyses of garnet were made with LAICPMS at the Centre for Isotope Research, VSEGEI, St.Petersburg, Russia. Methods and operating conditions have been described by Norman et al., 1996 .

Garnet from grospydites is characterized by a flattened type of REE distribution with depletion in the area of HREE and enrichment in the area of LREE and by a welldefined positive Eu anomaly (Fig. 3 top).

By distribution pattern of REE, garnets from grospydites take an absolutely isolated place relative to garnets of various eclogites of the Grib pipe. As for HREE and MREE, garnets from grospydites are analogous to garnets from eclogites of group $\mathrm{C}$ (including small positive $\mathrm{Eu}$ anomaly). As for LREE, garnets from grospydites are analogous to garnets from eclogites of group B and differ drastically from eclogites of group A.

Garnets from grospydites are characterized by the low contents of $\mathrm{Y}, \mathrm{Zr}, \mathrm{Ti}, \mathrm{V}$ (Fig. 3 bottom), which makes them similar to garnets from eclogites of group $\mathrm{C}$ (and to some extent, of group B), and sharply contrast to the garnets from eclogites of group A. 


\section{$10^{\text {th }}$ International Kimberlite Conference, Bangalore - 2012}
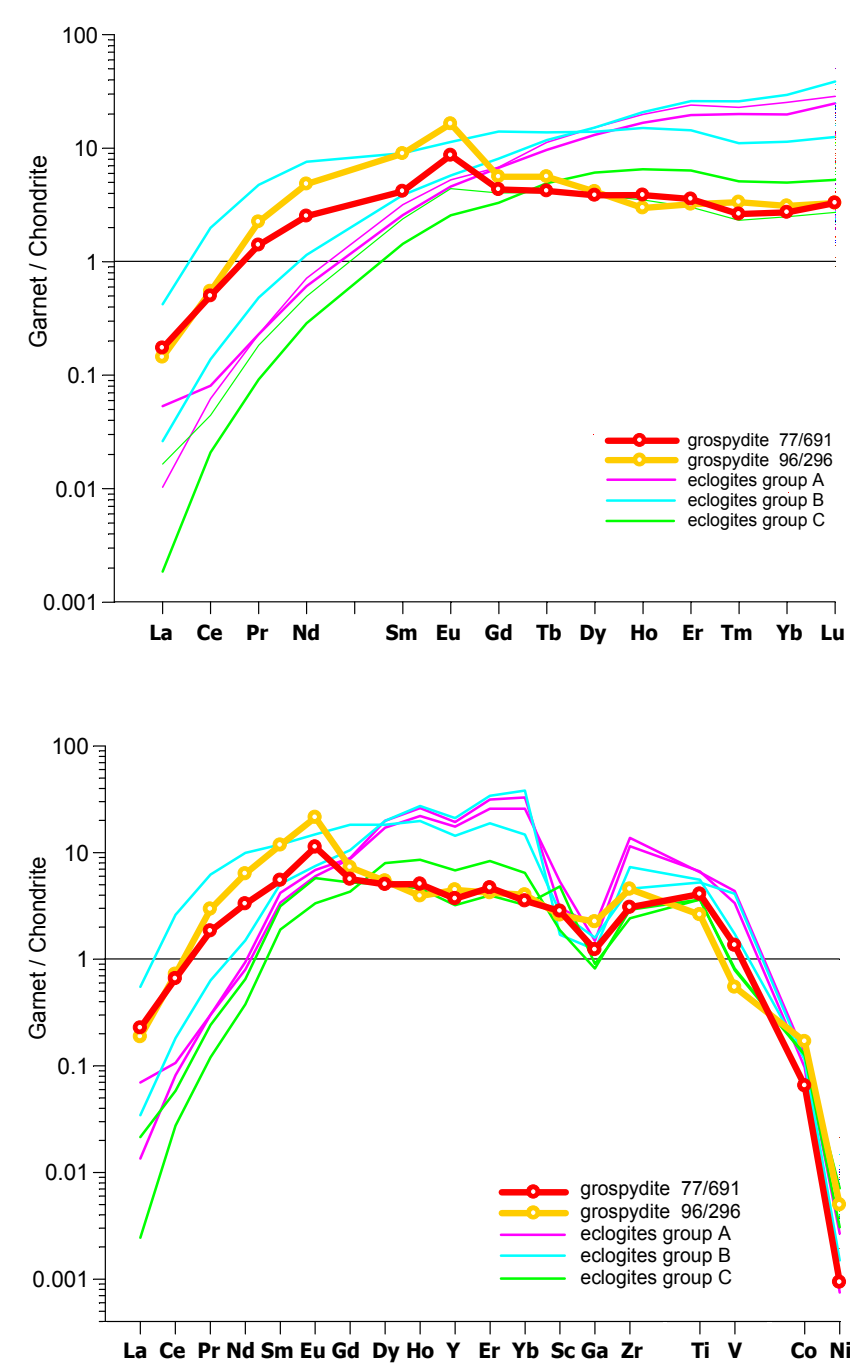

Fig. 3. REE (top) and trace element (bottom) patterns of garnets in the Grib pipe grospydites and different type eclogites.

\section{Oxygen isotopes}

Isotopic composition of oxygen in garnets from grospydites $\left(\delta^{18} \mathrm{O}=4.99\right.$ and $5.60 \%$ \% , as a whole, corresponds or is very similar to the typical mantle values $\left(\delta^{18} \mathrm{O}=5.5+/-0.4 \%\right.$ oo (Mattey et al., 1994). Mantle values of $\delta^{18} \mathrm{O}$ are also characteristic for eclogites of group $\mathrm{C}$ $(5.18-5.29 \%$ o $)$. Garnets from eclogites of groups A and B are characterized by both typical mantle values of $\delta^{18} \mathrm{O}$ $(5.46-5.53 \%)$ and light isotopic composition of oxygen $\left(\delta^{18} \mathrm{O}=4.03-4.66 \%\right.$ оo $)$.

In general, all garnets of all studied types of xenoliths of eclogite rocks from Grib pipe are characterized by typical mantle oxygen isotope values (Fig. 4), or slightly "light" oxygen isotopic composition (similar results were obtained earlier for garnets from xenoliths of eclogite groups A and B of Grib pipe - Malkovets et al., 2003).

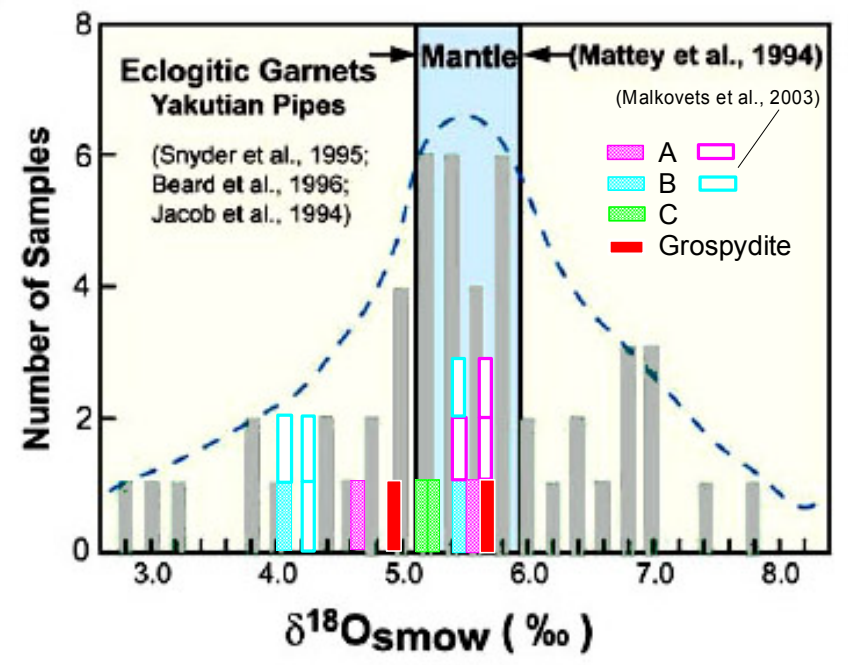

Fig. 4. Oxygen isotope values for eclogitic garnets from the Grib pipe (diagram after Taylor et al., 2003).

High-Ca (high-grossular) garnet and omphacite-jadeite macrocrysts.

In addition to rare xenoliths of grospydites in Grib's pipe, one can find rare mineral macrocrysts that are characteristic of high-aluminium eclogitic rocks. These high-calcium (high-grossular) garnets and high-sodium clinopyroxenes of eclogitic paragenesis similar to garnets of megacryst association by their size and shape of precipitates.

Garnet grains are oval or angular-flattened shape, the size is $2-2.5 \mathrm{~cm}$, and characterized by a yellowish-pink or pinkish-yellow color (Fig. 5).

By chemical composition (Table-2), these garnets correspond to grossular-pyrope with a high content of $\mathrm{CaO}$ $(13,30-16,16$ wt.\%) and a high proportion of grossular minal (32.7-39.8\%).

By distribution of REE and rare elements (Fig. 6), these garnets are close to garnets precisely from grospydites, differing from the latter only by more sterility with heavy $\mathrm{REE}$ and the increased content of $\mathrm{Zr}$.

Macrocrysts of clinopyroxene are oval in shape, the size is up to $7 \mathrm{~cm}$ (Fig. 7), and by chemical composition they correspond to high-aluminium omphacite-jadeite with the content of $\mathrm{Na}_{2} \mathrm{O} \quad 7.52 \%$. Clinopyroxenes of this composition are characteristic of eclogites of group $\mathrm{C}$. 


\section{$10^{\text {th }}$ International Kimberlite Conference, Bangalore - 2012}
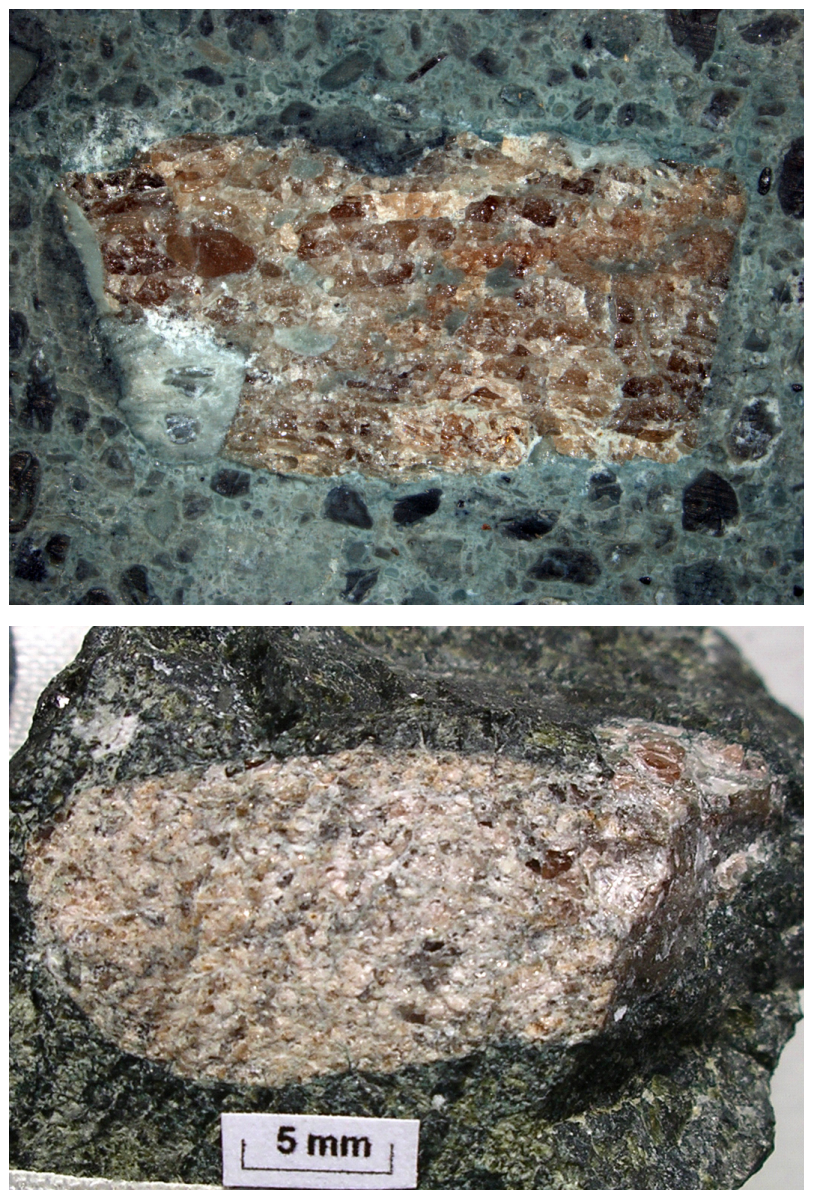

Fig. 5. Megacryst garnets in the Grib pipe: top - sample $96 / 261$; bottom sample 96/465.

Table-2. Chemical composition of macrocryst minerals (wt. \%).

\begin{tabular}{|c|c|c|c|}
\hline Sample & $96 / 261$ & $96 / 465$ & $9 \mathrm{c} / 578$ \\
\hline Minerale & Grt & Grt & $\mathrm{Cpx}$ \\
\hline $\mathrm{SiO}_{2}$ & 41.15 & 41.58 & 56.60 \\
\hline $\mathrm{TiO}_{2}$ & 0.12 & 0.24 & 0.37 \\
\hline $\mathrm{Al}_{2} \mathrm{O}_{3}$ & 22.32 & 22.72 & 10.52 \\
\hline $\mathrm{Cr}_{2} \mathrm{O}_{3}$ & 0.00 & 0.01 & 0.65 \\
\hline $\mathrm{FeO}$ & 7.52 & 7.64 & 3.57 \\
\hline $\mathrm{MnO}$ & 0.05 & 0.08 & 0.13 \\
\hline $\mathrm{MgO}$ & 13.95 & 12.06 & 9.97 \\
\hline $\mathrm{CaO}$ & 13.30 & 16.16 & 10.33 \\
\hline $\mathrm{Na}{ }_{2} \mathrm{O}$ & 0.10 & 0.11 & 7.52 \\
\hline $\mathrm{K}_{2} \mathrm{O}$ & - & - & 0.00 \\
\hline $\mathrm{Total}$ & 100.52 & 99.48 & 100.81 \\
\hline $\mathrm{Grossular} \%$ & 32,7 & 39,8 & - \\
\hline
\end{tabular}
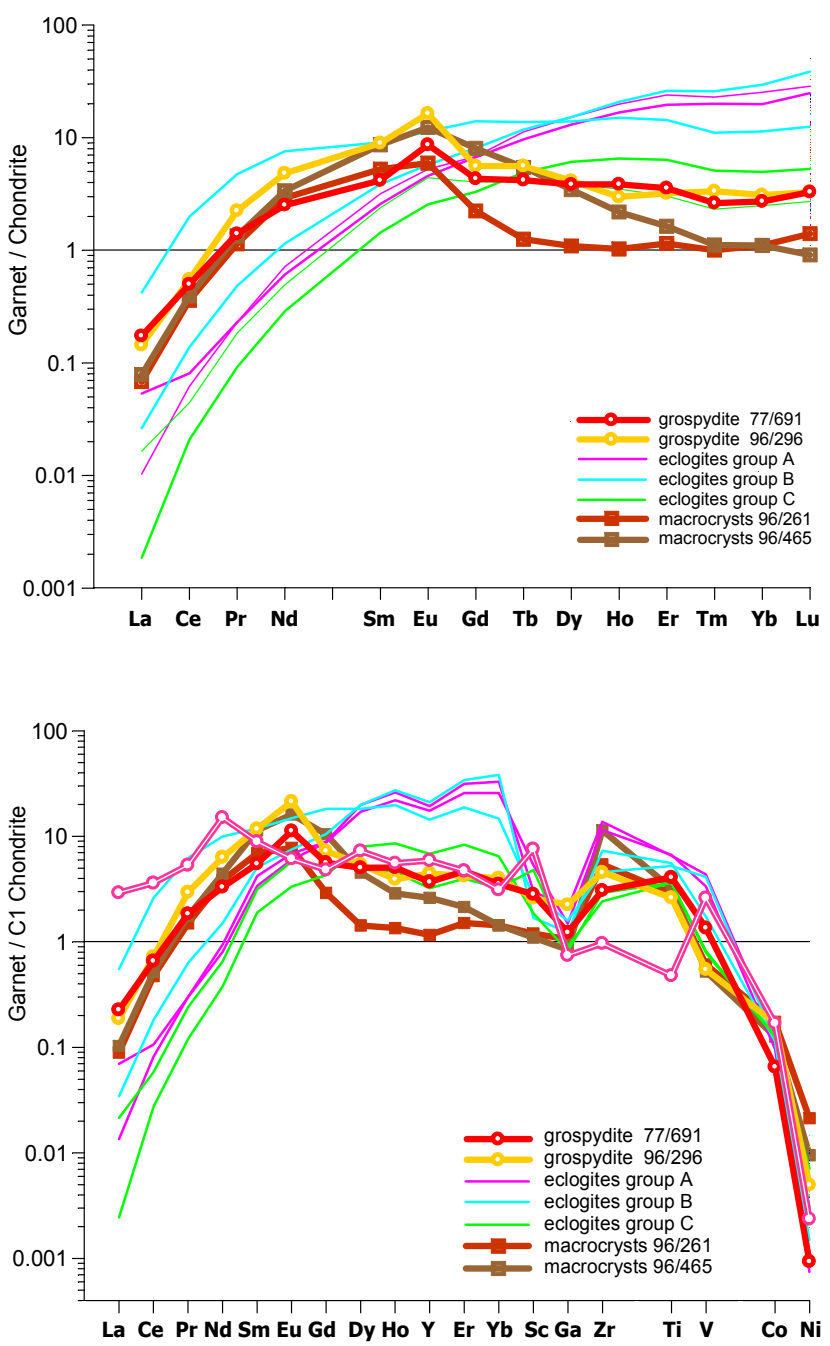

Fig. 6. REE (top) and trace element (bottom) patterns of garnets in the Grib pipe macrocrysts and different type eclogites.

\section{CONCLUSIONS}

Presence of grospydite xenoliths and high-alumina eclogites group $\mathrm{C}$ and eclogitic macrocrysts, distribution pattern of REE and heterogeneous isotopic composition of oxygen in garnets from eclogites of the Grib pipe may testify to a wide development of subduction processes in the Zimni Bereg area. 


\section{$10^{\text {th }}$ International Kimberlite Conference, Bangalore - 2012}

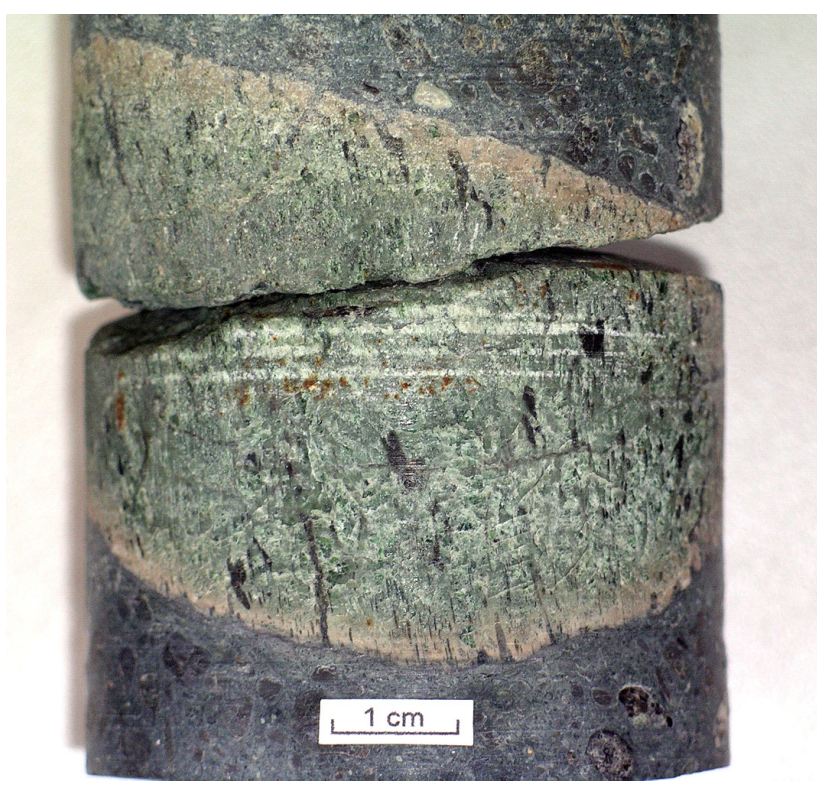

Fig. 7. Clinopyroxene (omphacite-jadeite) macrocrysts in the Grib pipe: sample $9 \mathrm{c} / 578$.

\section{References}

Bobrievich A.P., Bondarenko M.N.,Gnevushev M.A., Krasov L.M., Smirnov G.I., Yurkevich R.K. (1959) Diamond deposits of Yakutia. Moscow. P. 210 (in Russian).

Coleman R.G., Lee, D.E., Beatty, L.B. and Brannock, W.W., (1965). Eclogites and eclogites: their differences and similarities. Bull. Geol. Soc. Amer. 76, 3, 483-508

Malkovets V., Taylor L., Griffin W., O'Reilly S., Pokhilenko N., Verichev E., Golovin N., Litasov K., Valley J. and Spicuzza M. (2003) Eclogites from the Grib kimberlite pipe, Arkhangelsk, Russia. $8^{\text {th }}$ IKC. Victoria. Exstented Abstracts.

Mattey, D., Lowry, D., Macpherson, C. (1994). Oxygen isotope composition of mantle peridotite. Earth Planet. Sci. Lett. 128, 231-241.

Norman, M.D., Pearson, N.J., Sharma, A.,Griffin, W.L. (1996). Quantitative analysis of trace elements in geological materials by laser ablation ICPMS: instrumental operating conditions and calibration values of NIST glasses. Geostand. Newsl. 20, 247-261.

Sablukova L.I., Sablukov S.M., Verichev E.M., Golovin N.N. (2003) Petrography and mineral chemistry of mantle xenoliths and xenocrysts from the Grib pipe, Zimny Bereg area, Russia// Proceedings of International Workshop «Plumes and problems of deep sources of alkaline magmatism» (Khabarovsk), Khabarovsk, p. 65-95.

Taylor L.A., Spetsius Z.V., Wiesli R., Anand M., Promprated P., and Valley J.W. (2003) The origin of mantle peridotites: crustal signatures from Yakutian kimberlites. $8^{\text {th }}$ IKC. Victoria. Exstented Abstracts. 